\title{
Judicial review of parliamentary legislation: Norway as a European pioneer
}

\author{
by the Hon Justice Carsten Smith, President of the Norwegian \\ Supreme Court
}

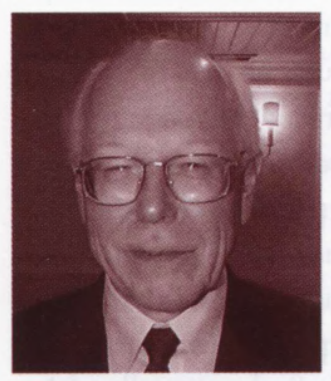

Hon Justice Carsten Smith
The following is an abridged version of the Coffin Memorial Lecture on the History of Ideas given earlier this year at the IALS.
Dr Carsten Smith, the Chief Justice of Norway (and an Honorary Fellow of SALS), delivered the University of London Annual Coffin Memorial Lecture on the History of Ideas at the Institute of Advanced Legal Studies on 3 April 2000. He spoke about 'Judicial Review of Parliamentary Legislation: Norway as a European Pioneer'. The Lord Chief Justice of England and Wales, Lord Woolf of Barnes, chaired the lecture. Many other senior judges and leading academics attended, including Lord Goff, Lord Slynn, Lord Nolan, Lord Hope and Lord Justice Mummery.

Chief Justice Smith was introduced by Lord Chief Justice Woolf. Chief Justice Smith served as the President of the Norwegian Supreme Court for a decade. Before that he established an international reputation as an academic in banking law. He was one of the youngest academics ever appointed to a professorial chair at the University of Oslo and his scholarship also covered international and human rights law. An article written by the young professor about the Supreme Court, human rights and the Constitution caused much comment, not all of it positive, from the then judges of the Supreme Court. He developed his views in the following years and for the last 10 years in the Supreme Court.
Whether it would have developed the same way without Chief Justice Smith as a member of the Court is a matter outsiders cannot know, but the views of the young professor have certainly been accepted by the Norwegian courts.

As a professor Dr Smith was often called upon as a one-person Supreme Court. The government sought his advice on important matters relating to the constitution, minority rights and banking. He is internationally known for the work he did for the Sami minority populating the north of Norway. One outcome of his recommendations is a new provision of the Norwegian Constitution about the rights of the Sami. Another is the Sami Parliament.

Lord Woolf pointed out that the experiences with judicial review in Norway had a particular relevance in the UK today, at the time of the entry into force of the Human Rights Act 1998. Norway had established judicial review of parliamentary legislation before any other European country. Recent Norwegian case law on the status of international and European law would also be of interest.

Below follow excerpts from Chief Justice Smith's lecture.

\section{THE HISTORY OF A LEGAL CONCEPT}

My subject is the history of a legal concept which spread throughout Europe - and the world at large - in the latter half of the twentieth century, but which had already grown roots in Norway a century earlier. It is the idea that law, as applied by the courts, shall function as a check upon parliamentary power.

The authority and the duty of the courts to set aside statutes on the ground that they violate provisions of the constitution of a country - to act as guardian of the constitution - represent a safeguard for individuals and minorities whose views have not prevailed in the political arena. There are various terms used for this constitutional law concept, which I shall here refer to as judicial review.

This review applies first and foremost to the protection of human rights as formulated in a national constitution. In his play 'An Enemy of the People' of 1882, the 
Norwegian dramatist Henrik Ibsen voiced the familiar maxim that the minority is always right. But prior to that, Norway's Supreme Court had already drawn its own, and somewhat more balanced, judicial conclusions.

Norway's Constitution dates from 1814 when the four hundred year old union with Denmark was dissolved. It is the oldest written constitution in Europe still in effect today. The Constitution makes no explicit mention of judicial review, quite in conformity with European constitutional thinking of that period. This review arose during the following decades from the practice of the Norwegian Supreme Court itself.

As a precursor to the review of legislation the Supreme Court established in its first few years the principle that decisions of the executive branch could be declared null and void by the courts of law. The motivation was simple but forceful: it was stated that there must be some place to which citizens can turn to have the errors of the authorities rectified.

The right also to review the legislature evolved in two different but interrelated stages. The initial stage consisted of the courts adopting the Constitution as an instrument of true legal norms, not merely political guidelines, but rules which could be applied in court decisions as supplementing ordinary statutes and other norms of law. A key factor in this regard was the extremely positive status of the Constitution in Norwegian popular opinion in the years following 1814. It was the prime symbol of the country's new-found independence, highly praised by poets and politicians, so why should not Norwegian judges also treat it with great respect? Once this stance had become firmly rooted, it was not a long next step to regard the relationship between the Constitution and statutory law as a regular legal relationship between a superior rule and a subordinate one.

The first breakthrough internationally occurred in 1803 with the US Supreme Court's decision in Marbury v Madison 1 Cranch 137, which represents one of the landmark cases in Western legal thinking. The closest comparable Norwegian decision was a case between a naval officer and the naval authorities of 1866 . Public voting was introduced in the Supreme Court only two years previously, and even if some decisions might be considered as forerunners, this case is our first example of a publicised judgment in which the principle of judicial review was clearly applied.

The case in question pertained to legislation requiring naval officers in certain positions to keep up-to-date lists of crew members without receiving any remuneration for this task. This was found to be incompatible with the Constitution. The Supreme Court awarded-eompensation to the disgruntled officer by four. votes to three.

In the Norwegian Supreme Court, each judge has to pronounce an individual vote with reasoning. It was the Chief Justice who in the final and decisive vote raised the issue of judicial review and gave the answer in the most unambiguous way, namely,

'that inasmuch as the courts of law cannot be required to judge according to both laws simultaneously, they must necessarily give priority to the Constitution'.

Norway's Supreme Court was apparently the first court in Europe to establish these kinds of judicial review powers. At around the same time Switzerland was starting to review the legislation of the cantons vis-à-vis the Constitution, but this review did not include federal legislation.

The Norwegian practice started in a period of political trend towards parliamentary rule, which was introduced in the 1880s. Historians have maintained that the new power of the Supreme Court should be regarded as a political move to substitute the Court for the independent government in the role as conservative guarantor, since the government now was in the process of losing its independent position in relation to Parliament. The sources are, however, scarce to evaluate this introduction of judicial review from a political point of view. In the judicial opinions of the Court one finds naturally only strictly legal language.

It is probable that the Norwegian judges at the time were aware of the American practice, although this is by no means certain. What is more certain is that our constitutional adjudication remained a relatively well-kept secret in an international perspective, effectively protected by linguistic barriers. In international literature on judicial review, Norwegian practice is very much an unknown quantity.

The next step internationally was the establishment of the Austrian constitutional court which was set up in 1920 at the instigation of the renowned legal scholar Hans Kelsen. Further development was of minor significance until after the Second World War, but when it came, it came hard and fast. After 1945 Germany and Italy set up similar courts, followed by a widespread blossoming of successive constitutional courts throughout Europe, particularly after the fall of the communist regimes. Powers of judicial review have also been introduced in other countries around the globe, in specialist courts or ordinary courts, in varying degrees.

In a Nordic context, the Norwegian jurisdiction stood out as a unique principle. Iceland had its national breakthrough in 1943, Denmark last year, whereas Sweden and Finland are still hesitating.

The concept of judicial review in Norway was created in the 19th century on the American model, and was modernised in the 20th century by adapting the preferred position principle to Norwegian conditions. This begs the question as to whether in the present century we will also dare to emulate the most recent practice adopted by the US Supreme Court - the application of non-textual constitutional rights. 
The seed of this latest development can be traced back to the 1960s, when for instance Harlan J spoke of the larger context of constitutional provisions, defining that context as one 'not of words, but of history and purposes'. The major breakthrough for such reasoning came with Roe v Wade 4100 US 113 in 1973. In that case the Supreme Court found that the Constitution recognised a general 'right to privacy' despite the fact that this is not explicitly stated in any of the constitutional articles - and moreover, that this 'right' must also be understood as widely as including the right to terminate a pregnancy.

But this is the line of constitutional thinking which also meets the greatest resistance. As Judge Robert Bork aphoristically put it:

'The truth is that the judge who looks outside the historic Constitution always looks inside himself and nowhere else.'

The idea of extrapolating implicit constitutional rights remains removed from the Norwegian concept so far. The Supreme Court has nonetheless tested these waters, although with extreme caution. Certain rulings have been worded carefully to allow future statutes to be set aside should they violate certain general legal principles of a fundamental nature. But at the same time it has been emphasised that this could only, if ever, be applicable in 'extreme cases'.

Most of the supplementation of the Constitution which would concur with Norwegian thinking can be achieved by applying the European Convention on Human Rights and the two United Nations Covenants. It is probable that these may present the Norwegian courts with some of their greatest legal challenges in the near future.

As a few concluding observations based on around a 150 years of judicial review, I should like to draw particular attention to certain points.

Firstly, on the legal basis: the principle was established long ago by constitutional customary law, according to the most common view in legal theory, which means that the principle can only be eliminated by a highly improbable amendment to the Constitution.

Second, on the democratic viewpoint: in the Norwegian debate on judicial review, the image has been used of a spanner thrown in the works of democracy. Admittedly, judicial review will necessarily entail a curtailment of the will of the parliamentary majority at a given moment. But judicial review does not always work in a conservative direction. It can also have a reforming effect, not least in protecting freedom of speech.

Third, on the organisation of the court system: judicial review can be carried out in a satisfactory manner through the ordinary courts, thereby avoiding splits in the court system, and reducing the risk of politicising the process. In the ordinary courts, as opposed to separate constitutional courts, judicial review will be implemented by judges whose main duties are ordinary application of the law, ensuring to a large degree that they apply recognised judicial methodology.

Fourth, on the range of the principle: judicial review can be carried out in a sober manner - more cautiously than for instance in the US - while still remaining an active part of the check and balance system in the public sector of the country. At the same time, the principle can be applied in such a way as to afford particularly strong protection to fundamental human rights.

And finally, on the history of the idea: even though the principle has encountered resistance at times, both in Parliament and in public debate, it has slowly taken root over the generations as an important element in the three branches of government. Thus judicial review shows according to Norwegian thinking - that the nation is not merely a democracy, but a democracy which in the last resort has a special institutional guarantee for the rule of law. ec

\section{One Day Historical Seminar}

\section{Saturday 2 December 2000}

Politics and Judiciary in Seventeenth and Eighteenth Century England

Speakers: DR CHRISTOPHER BROOKS, Reader, Department of History, University of Durham: Law, judges and politics in early Stuart England; DR MIKE MACNAIR, Fellow, St Hugh's College, Oxford: Locke, the constitution and the law of property in early eighteenth century Whig legal thought; DR ROSE MELIKAN, Fellow, St Catherine's College, Cambridge: Master of the House? Parliament and the Master of the Rolls during the reign of George III; PROFESSOR DAVID LEMMINGS, Department of History, University of Newcastle, Australia: Rethinking judicial independence in eighteenth century England.

The above seminar will take place from $11 \mathrm{am}-4 \mathrm{pm}$ at the IALS. It costs $£ 8.00$ per head (which includes lunch and refreshments), but some places are available free of charge. Those wishing to attend should contact contact Belinda Crothers at the Institute of Advanced Legal Studies (tel: $020 \quad 7862 \quad 5841$; email: bcrother@sas.ac.uk) as soon as possible. 